\title{
Anterior esthetic restoration using DSD (digital smile design) for a patient with congenital missing tooth of maxillary central incisor
}

\author{
Hye Jeong Park, Joon-Seok Lee* \\ Department of Prosthodontics, College of Dentistry, Dankook University, Cheonan, Republic of Korea
}

\begin{abstract}
The prosthodontic treatments in maxillary anterior teeth focus on achieving esthetic appearances. It is possible to improve the esthetic appearance by adjusting the shape, arrangement, and color of the maxillary anterior teeth. For anterior teeth restoration, it is necessary to evaluate the relationship of teeth, lip and gingival architecture with the facial profile of patient. Also, clinician needs to fully understand what the patient wants to. DSD (digital smile design) concept can be applied as a tool to improve communication with the clinician, technician and patient. In addition, DSD can help to meet the needs of the patient. In this case, it was impossible to achieve symmetry due to congenital missing of maxillary central incisor. The definitive treatment goal was to get the harmony of maxillary anterior teeth, lip and the patient's face. This case report describes that the patient and clinician got the satisfying esthetic outcome by using DSD. (J Dent Rehabil Appl Sci 2019;35(3):170-9)
\end{abstract}

Key words: esthetics; anterior tooth restoration; digital smile design

\begin{abstract}
서론
상악 전치부와 같이 심미성이 크게 요구되는 부위는 치 료 결과에 대하여 환자가 요구하는 바가 많으며, 최근에 는 환자들의 심미성에 대한 관심이 급격히 증가하면서 보철 치료에 대한 환자의 기대 또한 크다. 따라서 환자 가 요구하는 바를 정확히 파악하고 이를 잘 반영하는 보 철물을 제작할 필요가 있으며, 이를 위해서는 진단과 치 료계획에서 환자와 술자, 기공사 간의 원활한 의사소통 및 의견 교환이 필요하다. 심미 수복에서는 환자와의 의 사소통을 위해 주로 진단 왁스업을 시행한 모형을 사용 해왔는데, 최근 Mclaren과 Culp ${ }^{1}$ 등 여러 임상가들은 소 프트웨어 상에서 구내 및 구외 임상 사진을 이용하여 미 소 설계하는 방법을 추천하였다. Coachman 등 ${ }^{2,3}$ 은 이러 한 디지털 작업을 통해 치료 결과에 대하여 더 쉽고 효과

*Correspondence to: Joon-Seok Lee

Professor, Department of Prosthodontics, College of Dentistry, Dankook University, 119, Dandae-ro, Dongnam-gu, Cheonan, 31116, Republic of Korea Tel: +82-41-550-0256, Fax: +82-41-550-1975, E-mail: jseok2@hanmail.net Received: May 19, 2019/Last Revision: July 13, 2019/Accepted: July 16, 2019
\end{abstract}

적인 시각화가 가능하다고 하였으며, digital smile design (DSD) 개념을 주장하였다. DSD를 활용하면 환자와 술 자 및 보철 치료 과정에 참여하는 모든 사람들이 이러한 디지털 디자인에 쉽게 접근할 수 있고 의사소통의 효율 을 높이며, 치료 결과에 대해 쉽게 예측할 수 있다고 하였 다. Sulikowski와 Yoshida ${ }^{4}$ 는 전치부 심미 수복에 있어서 대칭성, 치축 경사와 치은 정점의 위치, 치은 구조와 외형, 절단부 배열과 치간 공극(embrasure), 치아의 비율, 입술 선(lip line)을 고려해야 한다고 하였다. 이러한 고려 사항 들을 반영하는 치아 외형을 $\mathrm{DSD}$ 를 이용하여 설계하고, 이를 환자에게 제시함으로써 의견을 서로 교환할 수 있는 데, 사진으로 시각화 된 자료를 활용하기 때문에 환자가 치료 결과를 예측하기 쉽고 의사소통에도 도움이 된다.

본 증례의 환자는 선천적으로 상악 우측 중절치가 결 손되어 3절치 상태였으며, 결손치가 존재함에도 불구하

Copyright(C) 2019 The Korean Academy of Stomatognathic Function and Occlusion. (c) It is identical to Creative Commons Non-Commercial License. 
고 가용 공간이 없어 대칭성 및 황금비율을 고려한 보철 물 설계가 어려운 상황이었다. 이에 심미 수복을 위한 여 러 요소들의 절대적인 계측치 및 황금비율을 고수하기 보다는 환자의 안모와 조화를 이루는 자연스러움을 추 구하는 것을 치료의 궁극적인 목표로 하였으며, 이를 위 해 진단 및 치료계획에 DSD 개념을 활용하였고 이후 통 상적인 방법을 거쳐 보철 치료를 진행하였다. 치료 결과, 환자와 술자 모두 심미적, 기능적으로 만족할 만한 결과 를 얻어 이에 대하여 보고하고자 한다.

\section{증례보고}

본 증례의 환자는 53세의 여성으로, 상악 좌측 중절치 의 변색 및 크기 이상, 상악 좌측 측절치의 외상으로 인한 치수 침범이 있는 치관 파절을 주소로 본원에 내원하였 다(Fig. 1). 환자는 상악 중절치 한 개가 선천적으로 결손 된 3절치 상태로, 하나만 존재하는 상악 중절치는 양측 측절치에 비해 치관 폭경이 다소 커 보였으며, 하악 또한 3절치 상태로 상하악 치아의 정중선은 일치시킬 수 없는 상태였다(Fig. 2). 초진 시 환자는 상악 좌측 측절치의 근 관 치료 후 임시치아를 수복한 상태로, 이에 최종 보철물 을 제작하고자 하였으며, 동시에 상악 좌측 중절치의 변 색 및 크기 이상을 보철물 수복을 통하여 개선하고자 하 였다.

Sulikowski와 Yoshida ${ }^{4}$ 가 언급한 전치부 심미 수복에 서 고려해야할 요소들을 초진 시 촬영한 구내 사진 및 안 모 사진(Fig. 3)을 활용하여 이미지 편집이 가능한 소프트 웨어(Keynote, iWork Apple, Cupertino, USA) 상에서 분 석하였다.
증례의 환자는 상악 전치의 절단부를 잇는 곡선과 하 순이 평행하지 않은 것이 관찰되었고, 상악 중절치는 양 측 측절치에 비해 치관 노출량이 더 많았다. 전치부의 치 은선과 치은 정점의 위치는 양호한 편이었다. 중절치와 견치의 치은 정점(gingival zenith)은 유사한 높이였으며 측절치는 그보다 약 $1 \mathrm{~mm}$ 절단 측에 위치되어 있었다. 그러나 환자는 선천적으로 중절치 한 개가 결손되어 전 치부 치아 개수에 있어서는 좌우의 대칭성을 구현할 수 는 없는 상태였다.

환자는 가운데 있는 앞니가 너무 크다고 호소하였는 데, 이러한 주소를 해결하기 위한 치아의 외형을 디자인 하기 전 상악 중절치의 크기가 실제로 큰 것인지를 분석 하였다. 아시아인들을 대상으로 한 치관 폭경/길이 비율 에 대한 Marcushamer 등 ${ }^{5}$ 의 연구에서 상악 중절치의 치 관 폭경/길이 비율은 평균 0.72 (range: 0.65 - 0.81), 상 악 측절치와 견치는 평균 0.67 (range: 0.57 - 0.77)로 나타 났다. 환자의 치관 폭경/길이의 비율을 분석한 결과, 중 절치(\#21)에서 0.81 , 좌우 측절치에서 각각 $0.80,0.82$, 좌 우 견치에서 각각 $0.81,0.90$ 을 나타내었다(Table 1). 환 자는 좌우 측절치와 견치의 치관 폭경/길이 비율이 정상 범위보다 크고, 실제로는 측절치와 견치의 치관 길이가 작은 편임을 알 수 있었다.

중절치(\#21)의 치관 폭경/길이 비율이 정상 범위 내에 있었음에도 불구하고 환자는 중절치 크기의 조정을 원하 였다. 중절치의 치축은 다소 원심경사를 나타내었고, 치 관이 회전되어 주변 치아에 비해 돌출되어 있는 경향을 보였다. 환자는 이 또한 개선을 원하여 이를 모두 반영하 기 위해 Keynote 상에서 치아의 비율을 조절하였다. 중 절치(\#21)의 치관 길이를 감소시키고, 좌측 측절치(\#22)
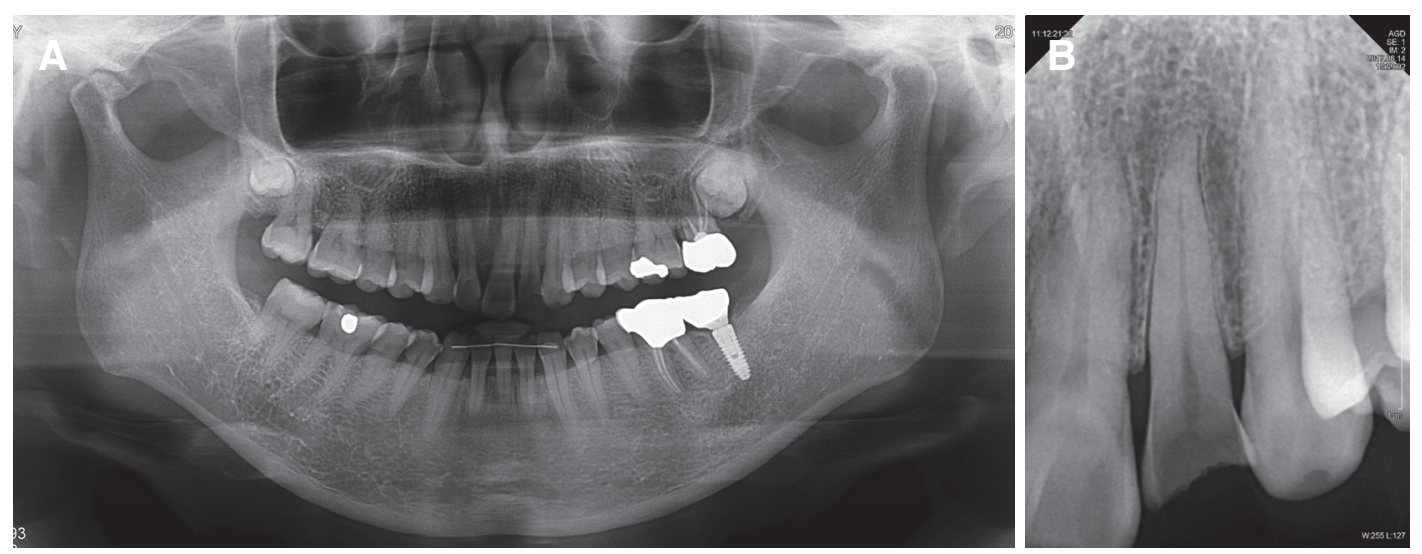

Fig. 1. Initial radiographic image. (A) Panoramic view, (B) Periapical view. Crown fracture with pulpal exposure is shown. 

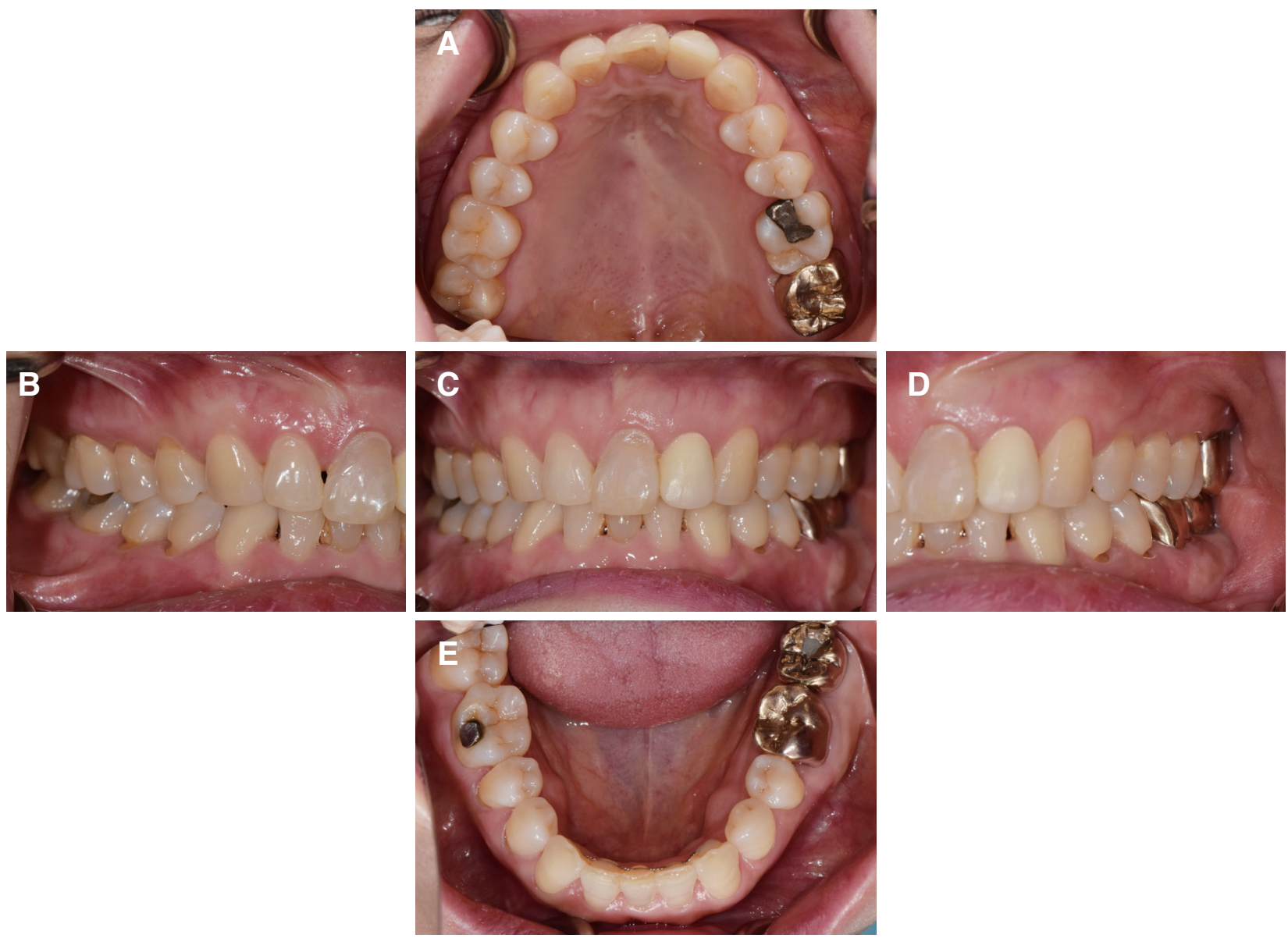

Fig. 2. Pretreatment intraoral view showing missing of maxillary central incisor. (A) Occlusal view of maxilla, (B) Right lateral view, (C) Frontal view, (D) Left lateral view, (E) Occlusal view of mandible.

Table 1. Measurement of the width and length of the pretreatment teeth on the dental cast

\begin{tabular}{|c|c|c|c|c|c|}
\hline & \#13 & $\# 12$ & \#21 & $\# 22$ & \#23 \\
\hline Width & 7.68 & 6.96 & 8.62 & 7.45 & 7.82 \\
\hline Length & 8.51 & 8.49 & 10.91 & 9.28 & 9.62 \\
\hline Proportion $(\mathrm{W} / \mathrm{L})$ & 0.9 & 0.82 & 0.81 & 0.8 & 0.81 \\
\hline
\end{tabular}

Table 2. Measurement of the width and length of the modified teeth on the diagnostic wax-up cast

\begin{tabular}{lllrlll}
\hline & $\# 13$ & $\# 12$ & $\# 21$ & $\# 22$ & \#23 \\
\hline Width & 7.68 & 6.96 & 8.02 & 6.86 & 7.82 \\
Length & 8.51 & 8.49 & 10.73 & 9.24 & 9.62 \\
Proportion (W/L) & 0.9 & 0.82 & 0.75 & 0.74 & 0.81 \\
\hline
\end{tabular}

의 치관 폭경을 감소시켜 치관 폭경/길이 비율을 조절하 였다. 동시에 중절치(\#21)의 회전 정도 또한 조절하였다. 중절치의 치관 길이는 수치적으로는 약 $0.2 \mathrm{~mm}$ 감소시 켰는데, 이는 하순의 입술선과 전치부 절단연이 평행함을 유지할 수 있도록 그 양을 조절한 결과이다. 좌측 측절치
는 치관 폭경을 조절하여 치관 폭경/길이 비율을 감소시 켰다(Table 2).

Keynote로 디자인한 치아 외형의 이미지를 환자에게 직접 보여주고, 환자의 의견을 반영하고자 하였다. 초진 시 촬영해 두었던 구내 사진 및 안모 사진을 이용하여 치 
아의 외형을 디자인하였다. 중절치(\#21)는 근심 치경부 를 초진시보다 보다 더 풍융하게 만들어주었고, 치은연 (gingival margin)의 외형도 수정하여 근심측 치은연이 초 진시보다 더 치근단 쪽에 위치하도록 디자인하였다. 중 절치(\#21)의 근심부가 풍융해지면서 우측 측절치(\#12) 의 근심측도 함께 수복하는 것이 심미적일 것으로 진단 하여 처음 디자인에서는 \#12도 포함하여 보철 수복하 는 것으로 설계하였다. 그러나 환자는 최소한의 치료만 을 원하여 중절치(\#21)와 좌측 측절치(\#22)만 수복하기 로 하였고, 이에 치아 외형을 수정하여 디자인하였다. 이 를 다시 환자에게 확인시켜 주었는데, 술자와 기공사가 처음 디자인했던 중절치의 길이가 다소 길어 보인다고 하
여, 환자의 의견을 수렴하여 디자인을 재차 수정하였다. 이렇게 3 회 이상의 이미지 수정 작업을 거친 최종 디자인 이 Fig. 4의 형태이다.

알지네이트 인상을 채득하여 진단 모형을 제작하였고, 교합평면의 정보를 교합기 상에 이전하기 위하여 안궁 이전을 시행하였다. 이후 진단 모형을 반조절성 교합기 (Hanau modular articulator system 190, Whip Mix Co., Luisville, USA)에 마운팅하였다. 최종 디자인의 치아 외 형과 동일한 치아 비율을 기준으로 진단 납형을 제작하 였다(Fig. 5). Keynote의 디자인을 재현한 진단 납형을 환 자와 함께 확인하면서 반복적으로 의견을 교환하였다.

진단 납형만으로는 환자의 안모 및 구내에서의 조화로

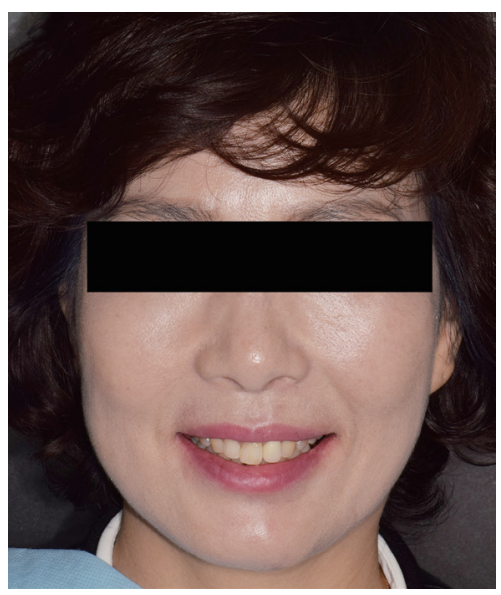

Fig. 3. Facial view of pretreatment aspect. Midline discrepancy and discoloration of maxillary central incisor are shown.
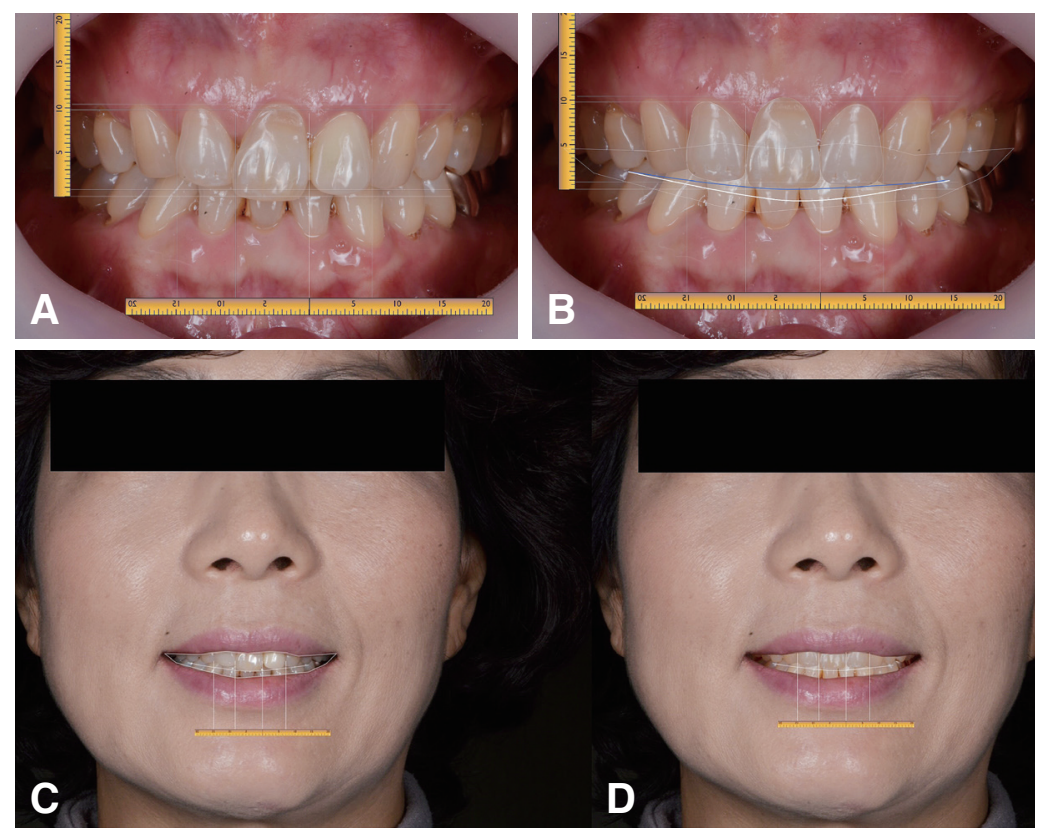

Fig. 4. DSD (digital smile design). (A) Analysis of shape of preoperative teeth, (B) Shape of designed teeth and smile arc(pretreatment; white bold line, modified; blue bold line). Comparison the aspect of teeth on patient's face. (C) Pretreatment teeth, (D) Modified teeth.
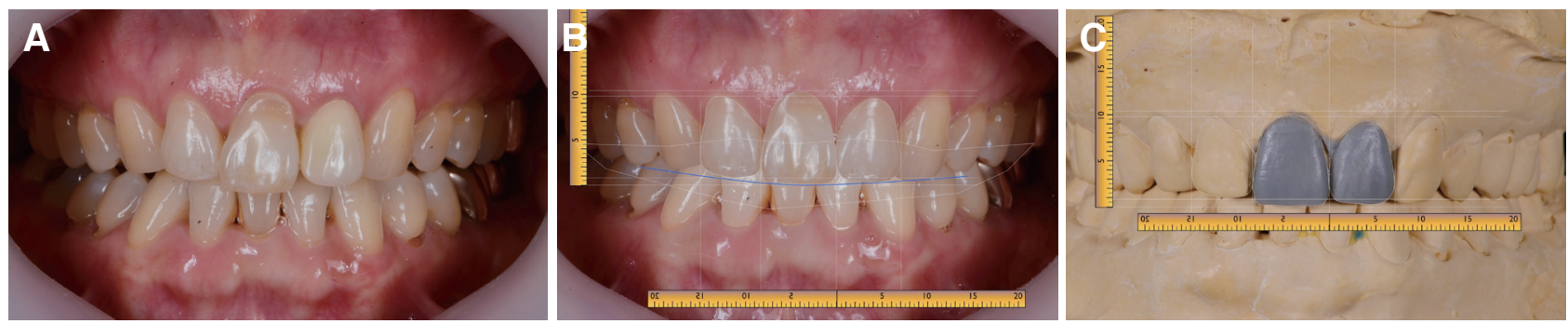

Fig. 5. The diagnostic wax-up is fabricated using the DSD as a guide. (A) Pretreatment view, (B) DSD (digital smile design), (C) Diagnostic wax-up. 
운 정도를 환자가 쉽게 예측하기 어려워 mock-up을 시 행하였다(Fig. 6). 진단 납형 상에서 putty index (Silagum, DMG, Hamburg, Germany)를 채득하고 bis-acrylic resin (Luxatemp, DMG)을 이용하여 임시 수복물을 제 작하였다(Fig. 7). 임시 수복물을 제작하여 구강 내 장착 후, 진단 과정에서 디자인한 치아 외형 및 환자가 원하는 치아 외형이 적절히 구현되었는지를 평가하였다. 이 임시 수복물은 4주 이상 사용하면서 환자의 의견을 반영하여 환자가 만족할 때까지 그 외형을 반복적으로 수정하였다.

임시 수복물에서 얻은 정보를 바탕으로 최종적인 치아 삭제를 시행하였다. Putty index를 미리 제작해두고 삭제

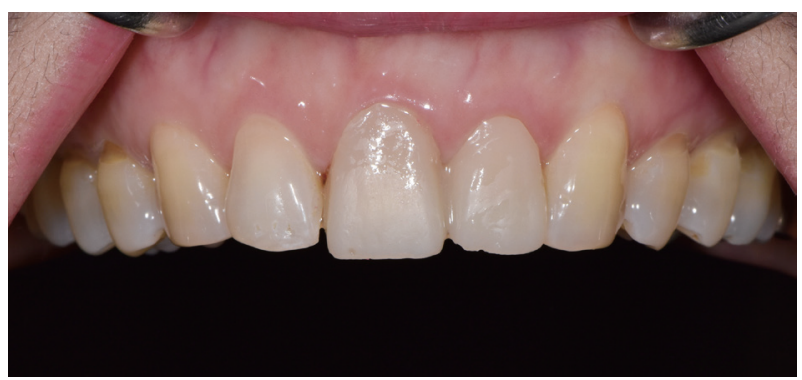

Fig. 6. Mock up.
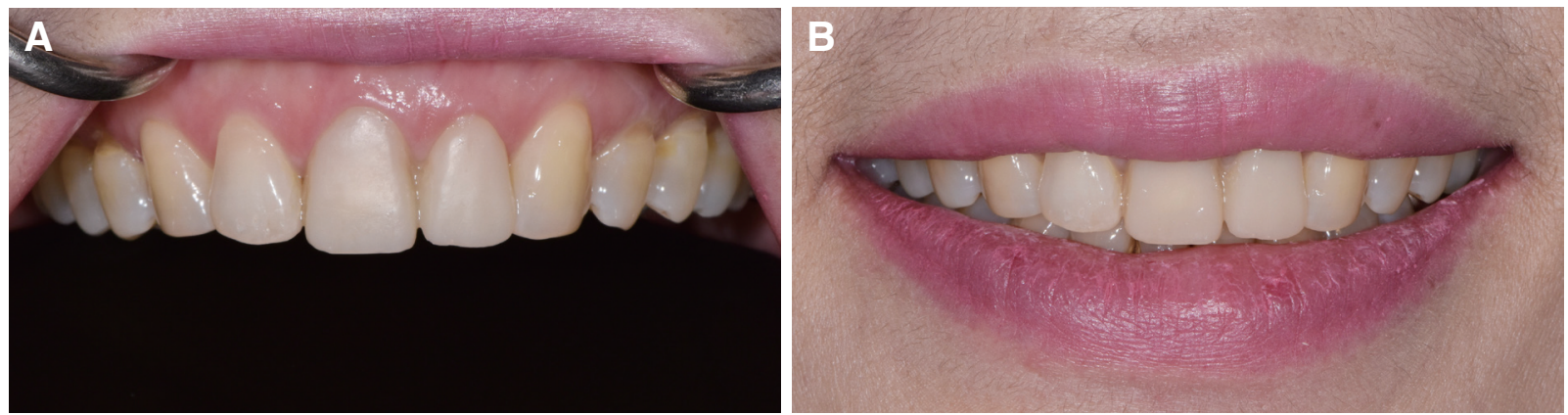

Fig. 7. Provisional restoration. (A) Cemented as a long-term provisional, (B) Frontal view of provisional restoration.
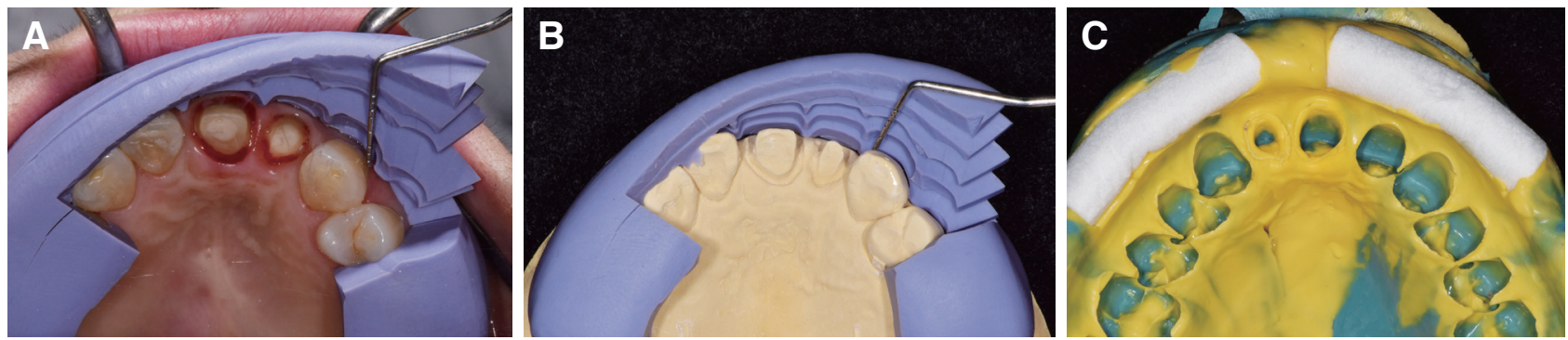

Fig. 8. Tooth preparation and impression taking. (A) and (B) The putty index was used to guide and check the amount of reduction, (C) Final impression taking with VPS. 

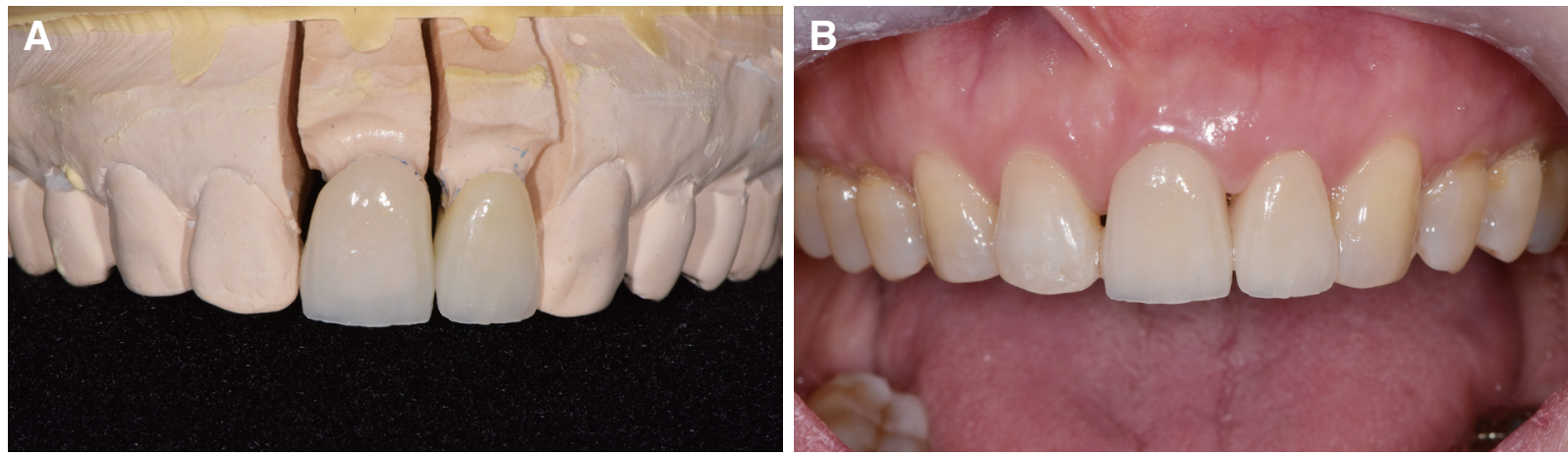

Fig. 9. IPS E.max coping try-in. (A) Positioning the coping on dental cast to verify marginal adaptation, alignment, (B) Coping try-in.
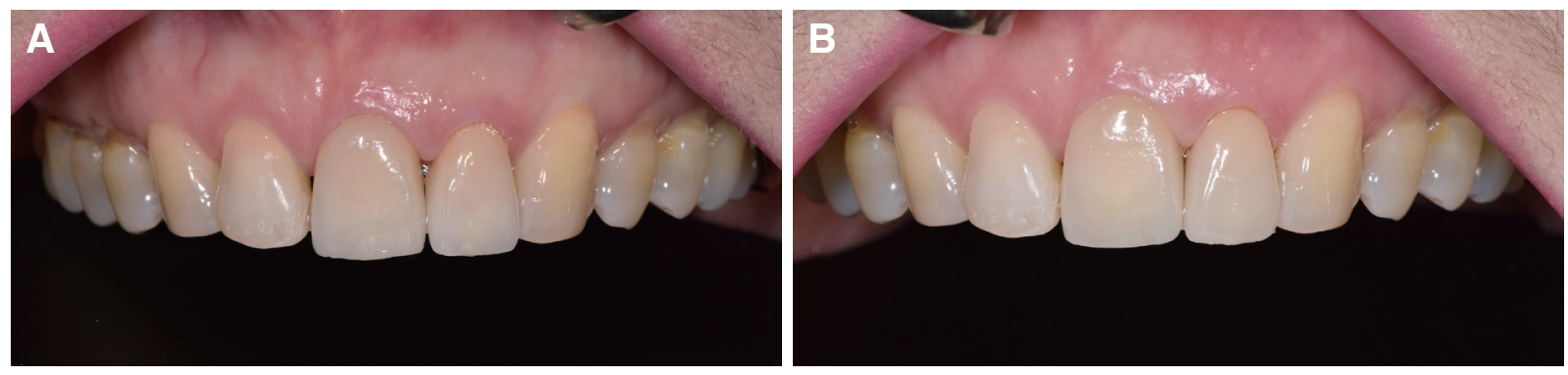

Fig. 10. Definitive prosthesis is fabricated. (A) Shade A1, (B) Shade A2.
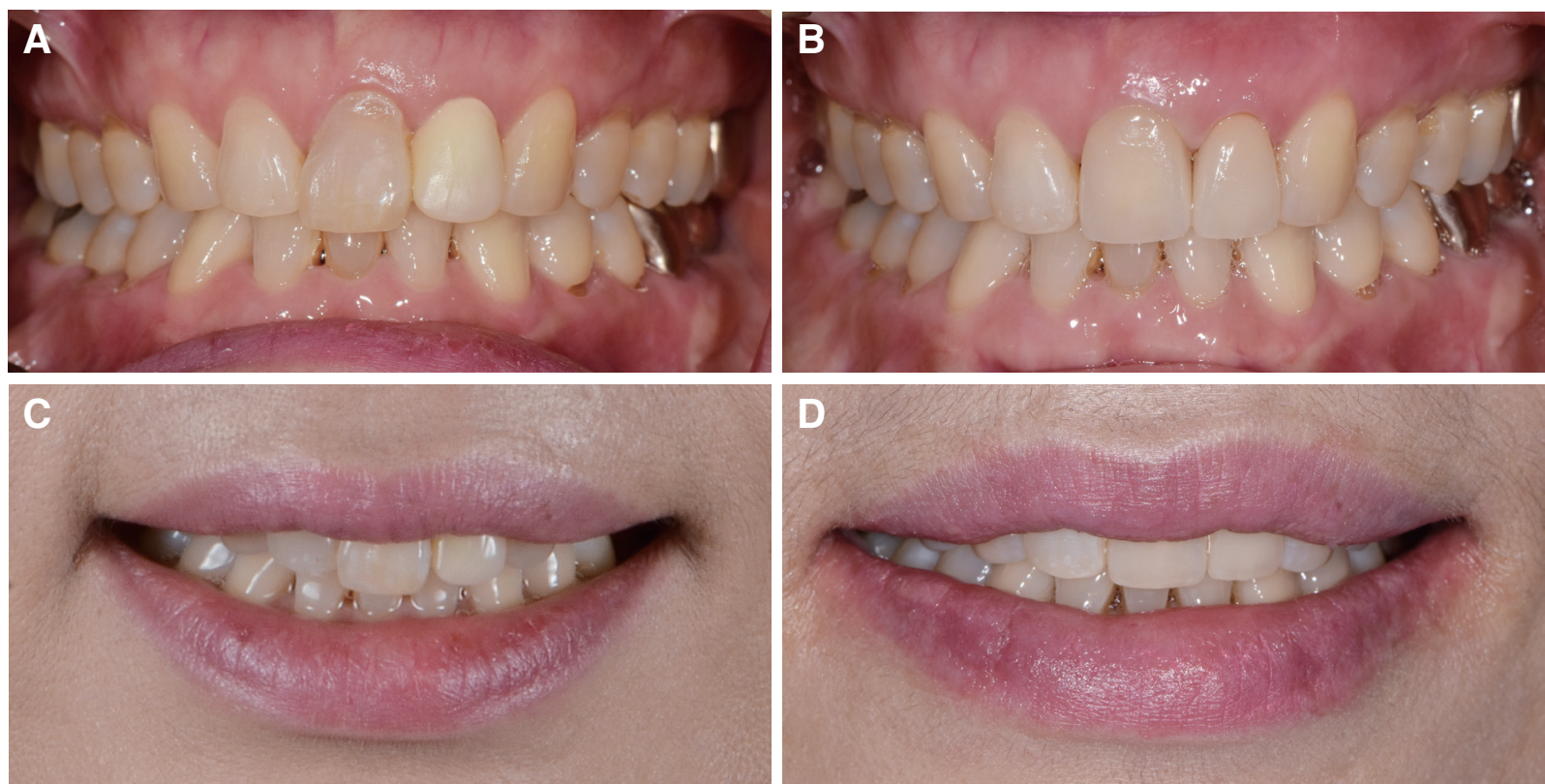

Fig. 11. Analysis of intraoral view and extraoral view. (A) Before treatment, (B) After treatment. Esthetics of prosthesis is improved and the discoloration of central incisor is relieved. (C) Smile line before treatment, (D) Improved smile line after treatment. 


\section{고찰}

성공적인 전치부 심미 수복을 위해 고려할 사항으로는 여러가지가 있다. 본 증례에서는 DSD 개념을 적용하여 치아 외형을 디자인하는데 있어서 Sulikowski와 Yoshida ${ }^{4}$ 가 언급한 대칭성, 치축 경사, 치은 정점의 위치, 치은 구 조와 외형, 절단부 배열과 치간 공극(embrasure), 치아 비 율, 미소선 등의 요소를 최대한 고려하였다.

Sabri ${ }^{6}$ 는 입술선(lip line)은 미소시 노출되는 상악 전치 부의 수직적인 양을 의미하여, 평균 $5.92 \mathrm{~mm}$ 가 이상적 이라고 하였다. 또한 Smile arc는 상악 전치부의 절단을 연결하였을 때 생기는 가상의 곡선과 미소시 하순의 안 쪽 윤곽선과의 관계를 의미하는데 상악 전치부의 절단부 를 잇는 곡선(curve)과 하순이 평행하거나 일치하는 것이 심미적이며, 상악 치아는 제 2 소구치 또는 제 1 대구치까 지 노출되는 것이 심미적이라고 하였다. ${ }^{6} \mathrm{Chu}$ 등 ${ }^{7}$ 은 치은 선과 치은 정점의 위치에 대하여 중절치와 견치의 치은선 은 유사한 높이, 측절치는 그에 비해 약 $1 \mathrm{~mm}$ 정도 절단 측의 높이에 위치할 때 심미적이라고 하였다. 또한 상악 전치부 각각의 치은 정점은 각 치아의 폭경을 수직 이등 분한 선(vertical bisected midline)에서 중절치에서는 1.1 $\mathrm{mm}$, 측절치에서는 $0.3-0.4 \mathrm{~mm}$, 견치에서는 $0 \mathrm{~mm}$ 떨어 진 거리에 위치하는 것이 이상적이라 하였다. 아시아인을 대상으로 한 Marcushamer 등의 연구에서 상악 중절치 의 치관 폭경/길이 비율은 평균 0.72 , 상악 측절치와 견치 는 평균 0.67 였다. 본 증례에서 환자는 전치부의 치은선 과 치은 정점의 위치는 비교적 양호한 상태였으나, smile $\operatorname{arc}$ 와 하순의 윤곽선이 평행하지 않았다. 또한 치관 폭 경/길이 비율은 Marcushamer 등 ${ }^{5}$ 의 연구 결과와 비교하 였을 때 상악 중절치는 정상 범위, 측절치와 견치는 정상 범위보다 큰 값을 보였다. 이 같은 상황을 고려하여 전치 부의 외형을 디자인하기 위해 DSD를 이용하였다.

전치부의 심미 수복에서는 지대치의 변색 여부 또한 고 려 대상이며, 이를 효과적으로 차폐하는 것이 중요하다. 전치부의 고정성 보철 치료에는 금속도재관이 통상적으 로 사용되어 왔는데, 금속도재관은 지대치의 변색에 대 한 차폐 효과는 있으나 치은 퇴축으로 인한 금속부의 변 연 노출, 치은 변색 등의 심미적인 한계가 존재한다. ${ }^{8}$ 금 속도재관은 내부의 금속 하부 구조의 색을 차단하기 위 해 사용하는 불투명(opaque) 도재로 인해 빛 반사율이 증가하여 몸체(body) 도재를 완전도재관에 사용하는 것 보다 더욱 불투명한 것을 사용하게 된다. 따라서 자연치
의 투명성을 재현하는데 다소 어려움이 있다. 그리고 치 경부는 불투명(opaque) 도재만 존재하여 빛 투과성이 떨 어지고 치경부에는 검은 그림자(shadow)를 발생시키게 되는 것이 단점이다. ${ }^{9}$ 금속도재관을 사용할 경우 치경부 변연 삭제량을 증가시켜 도재 변연을 부여하면 이런 현 상을 어느 정도 방지할 수 있다. ${ }^{9}$ 또한 치은이 두껍고 치 경부 삭제량을 충분히 확보할 수 있다면 이러한 현상을 감소시킬 수 있다. 하지만 본 증례의 환자는 변색치가 생 활치였기 때문에 치경부 변연의 삭제량을 증가시키는데 는 한계가 있었으며, 환자의 치은 색조가 어둡지 않고 두 께가 얇은 편이어서 금속도재관을 사용할 경우 치은부 가 검게 보일 가능성이 더 클 것으로 예상되었다. 따라서 더 나은 치료 결과를 위해서는 금속도재관보다는 완전도 재관으로 최종 보철물을 제작하는 것이 유리하다고 판 단되었다. 자연치와 유사한 심미성을 효과적으로 재현하 기 위하여 우수한 강도와 다양한 투명도 및 색조를 제공 할 수 있는 리튬 디실리케이트(lithium disilicate)인 ${ }^{10} \mathrm{IPS}$ E.max system을 사용하여 최종 보철물을 제작하였다.

보철 치료에 있어서 치료 결과의 질을 높이고 소요되는 시간을 보다 단축시키 위해서는 진료에 관여하는 모든 사람들의 원활한 의사소통이 중요하다고 생각된다. 이 를 위해 본 증례에서는 진단 및 치료 계획 과정에서 DSD 개념을 적용하였다. 디지털 이미지와 이미지 편집이 가 능한 프로그램만 구비되어 있다면 고가의 장비나 특정 한 전문적 프로그램을 구입할 필요없이 DSD 개념을 적 용한 디자인이 가능하다. ${ }^{11-13}$ 이미지 편집 프로그램으로 는 Keynote (iWork, Apple, Cupertino, USA) ${ }^{12,13-15}$ 또 는 Microsoft Powerpoint (Microsoft Office, Microsoft, Redmond, USA $)^{15}$ 와 같은 프레젠테이션 프로그램을 이 용할 수 있다. 본 증례에서는 이미지 편집에 Keynote를 이용하였으며 이는 프로그램 습득에 필요한 시간이 짧은 편이고 디지털 이미지를 편집하여 단시간 내에 시각화 시 킬 수 있는 것이 장점이다. 이렇게 디자인한 치아 외형은 진단 납형 제작을 통해 구현되고 프로그램 상의 디자인 과 비교하는 과정을 거치는 것이 대부분이다. ${ }^{11,12-16}$ 그러 나, 이러한 과정은 내원 횟수를 증가시켜 오히려 치료에 소요되는 시간이 증가 ${ }^{12,17}$ 할 수 있는 것이 단점이라고 생 각되며, 실제로 본 증례에서도 예상했던 것보다 환자의 내원 횟수가 훨씬 증가하여 총 치료에 소요된 시간이 증 가하였다. 이외에도 총 치료 비용도 함께 증가 ${ }^{13}$ 하는 결 과를 가져와 모든 환자에게 이를 적용하기는 어려울 것 으로 보인다. 치료에 소요되는 총 시간이 증가되는 단점 
을 극복하기 위해 $\mathrm{DSD}$ 를 통한 디자인을 $\mathrm{CAD}$ 소프트웨 어로 바로 옮기고 $\mathrm{CAM}$ 작업이 가능한 재료를 이용하여 임시 및 최종 보철물 제작에 소요되는 과정들을 모두 디 지털 작업으로 대체하는 방법 ${ }^{13}$ 이 보고되었다.

$\mathrm{DSD}$ 를 이용한 디자인은 환자가 치료 결과를 인지하 기는 쉽지만 2 차원적 이미지를 활용하는 것이기 때문에 치아의 순측 또는 협측면만 디자인하게 되는 경향이 있 고, 치아의 설면이나 인접면의 형태, 선각, 색조 및 질감 까지 입체적으로 디자인하여 제시하기는 어려운 측면이 있었다. 따라서 본 증례에서는 최종 디자인을 3 차원으로 재현할 수 있는 진단 납형을 제작하였으며, 구강내에서 mock-up ${ }^{18}$ 을 시행하였다. 진단 납형 상에서도 치아 외형 을 조금씩 수정하였고 이에 대한 환자의 확인을 반복하 였다. 이러한 최종 디자인을 반영한 임시 수복물을 제작 하여 일정한 기간 동안 사용하면서 환자가 임시 수복물 의 외형 및 사용감을 평가하도록 하였고 임시 수복물 역 시 외형을 반복적으로 수정하였다. ${ }^{17}$ 이러한 피드백을 통 해 얻은 임시 수복물의 디자인을 복제하여 IPS E.max system (Ivoclar vivadent, Schaan, Liechtenstein)을 사용 하여 하부 구조 상에 도재를 축성하는 방법으로 최종 보 철물을 제작하여 심미성을 향상시키는 결과를 얻을 수 있었다.

내원 횟수는 증가하였으나, 결과적으로는 최종 보철물 의 미세한 부분들의 조절을 위해서는 이 방법이 유리했던 것으로 보인다. 진단 납형 제작 및 미시적인 심미 요소의 조절을 위해서는 도재 축성 방식이 더 유리하다고 보고 된 바 있다. ${ }^{12}$

위에서 언급한 단점에도 불구하고, 진단 및 치료 계획 에서 DSD 개념을 적용하면 환자가 치료 결과에 대해 쉽 게 예측할 수 있고 치료 결과에 대하여 더 잘 받아들이는 효과가 있다. ${ }^{12,14}$ 환자의 사진 상에서 만든 치아의 디자인 을 환자에게 직접 보여주면서 설명하고, 환자의 요구사 항이나 수정이 필요한 사항을 반영하여 그 자리에서 바 로 디자인을 수정하는 등 즉각적인 피드백이 가능하다는 것은 $\mathrm{DSD}$ 의 큰 장점이다. ${ }^{14,15}$ 또한 환자와 술자, 기공사 간의 이러한 의견 교류를 통해 얻은 시각적인 자료를 통 하여 치료 결과의 한계를 미리 예측하고 환자가 이를 인 지하는 것도 가능하다. ${ }^{15}$ 평면적인 디자인 이외에도 입체 적인 디자인까지도 가능한 새로운 소프트웨어가 개발된 다면 $\mathrm{DSD}$ 의 장점을 극대화하는데 도움이 될 것으로 생 각된다.

\section{결론}

본 증례는 선천적으로 중절치가 결손된 5전치였으며 가용 공간이 전혀 없는 상태에서 좌우 대칭성 및 황금비 율을 구현하는 보철물 제작은 거의 불가능한 상태였다. 이에 진단 및 치료계획에 DSD 개념을 활용하여 환자와 술자 모두 만족스럽고 환자의 안모와 조화를 이루는 치 아 외형을 디자인하고자 하였다. 심미 수복을 위해 고려 해야 할 여러가지 요소들의 절대적인 수치보다 더욱 중 요한 것은 안모와의 전체적인 조화이다. $\mathrm{DSD}$ 를 통해 환 자의 안모와 조화를 이루는 치아 외형 및 배열, 미소선의 진단과 시각화를 보다 용이하게 할 수 있었다. 또한, 매 단계마다 환자와 의사소통하여 환자의 의견을 적극 반영 하고 치료 결과에 대해 환자가 더 잘 이해하고 받아들이 는 효과를 얻었다. 심미 보철 수복의 진단 및 치료계획시 $\mathrm{DSD}$ 를 활용하면 보다 시각화 된 자료를 통해 환자와 술 자 모두 만족하는 치료 결과를 얻는데 도움이 될 것으로 보인다.

\section{ORCID}

Hye Jeong Park https://orcid.org/0000-0003-1528-3376

Joon-Seok Lee https://orcid.org/0000-0003-2962-1380

\section{References}

1. Mclaren EA, Culp L. Smile analysis the photoshop smile design technique: Part I. J Cosmet Dent 2013;29:94-108.

2. Paolucci B, Calamita M, Coachman C, Gürel G, Shayder A, Hallawell P. Visagism: The art of dental composition. Quintessence Dent Technol 2012;35:187-200.

3. Coachman C, Calamita M. Digital smile design: a tool for treatment planning and communication in esthetic dentistry. Quintessence Dent Technol 2012;35:103-11.

4. Sulikowski A, Yoshida A. "Three-dimensional management of dental proportions: a new esthetic principle-"The frame of reference". Quintessence Dent Technol 2002;25:8-20.

5. Marcushamer E, Tsukiyama T, Griffin TJ, Arguello E, Gallucci GO, Magne P. Anatomical crown 
width/length ratios of worn and unworn maxillary teeth in Asian subjects. Int J Periodontics Restorative Dent 2011;31:495-503.

6. Sabri R. The eight components of a balanced smile. J Clin Orthod 2005;39:155-67.

7. Chu SJ, TAN JH, Stappert CF, Tarnow DP. Gingival zenith positions and levels of the maxillary anterior dentition. J Esthet Restor Dent 2009;21:11320.

8. Bagby M, Marshall SJ, Marshall GW Jr. Metal ceramic compatibility: a review of the literature. J Prosthet Dent 1990;63:21-5.

9. Magne P, Magne M, Belser U. The esthetic width in fixed prosthodontics. J Prosthodont 1999;8:106-18.

10. Isgrò G, Pallav P, van der Zel JM, Feilzer AJ. The influence of the veneering porcelain and different surface treatments on the biaxial flexural strength of a heat-pressed ceramic. J Prosthet Dent 2003;90:465-73.

11. Coachman C, Van Dooren E, Gürel G, Landsberg CJ, Calamita MA, Bichacho N. Smile design: From digital treatment planning to clinical reality. In: Cohen M (ed). Interdisciplinary treatment planning. Vol 2: Comprehensive case studies. Chicago; Quintessence; 2012. p. 119-74.

12. Shin S, Noh K, Kwon KR, Kim HS. Use of Digital Smile Design in esthetic restoration in anterior teeth: A case report. J Korean Acad Prosthodont
2017;55:164-70.

13. Meereis CT, de Souza GB, Albino LG, Ogliari FA, Piva E, Lima GS. Digital smile design for computer-assisted esthetic rehabilitation: two-year followup. Oper Dent 2016;41:E13-22.

14. Lin WS, Zandinejad A, Metz MJ, Harris BT, Morton D. Predictable Restorative Work Flow for Computer-Aided Design/Computer-Aided Manufacture-Fabricated Ceramic Veneers Utilizing a Virtual Smile Design Principle. Oper Dent 2015;40:357-63.

15. Pimentel W, Teixeira ML, Costa PP, Jorge MZ, Tiossi R. Predictable outcomes with porcelain laminate veneers: a clinical report. J Prosthodont 2016;25:335-40

16. Zanardi PR, Laia Rocha Zanardi R, Chaib Stegun R, Sesma N, Costa BN, Cruz Laganá D. The use of the digital smile design concept as an auxiliary tool in aesthetic rehabilitation: a case report. Open Dent J 2016;10:28-34.

17. Zandinejad A, Lin WS, Atarodi M, Abdel-Azim T, Metz MJ, Morton D. Digital workflow for virtually designing and milling ceramic lithium disilicate veneers: a clinical report. Oper Dent 2015;40:241-46.

18. Trushkowsky R, Arias DM, David S. Digital Smile Design concept delineates the final potential result of crown lengthening and porcelain veneers to correct a gummy smile. Int J Esthet Dent 2016;11:33854. 


\section{선천적 상악 우측 중절치 결손 환자에서 DSD (digital smile design)를 이용한 전치부 수복 증례}

\section{박혜정, 이준석 *}

단국대학교 치과대학 치과보철학교실

상악 전치부의 보철 수복은 치과 분야에서 심미성이 크게 요구되는 치료이다. 상악 전치부의 보철 수복을 통하여 치아 의 외형, 배열, 색조 등을 개선하면 심미성을 향상시키는 것이 가능하다. 특히 전치부 심미 수복을 위해서는 진단과정에 서 환자의 안모 및 치아와 입술과의 관계, 치아와 치은 관계 등을 평가하고, 환자가 요구하는 바를 정확히 파악할 필요가 있다. 환자와 술자 및 기공사 간의 원활한 의사소통을 통하여 환자의 요구사항을 충실히 반영하기 위한 도구로서 DSD (digital smile design) 개념을 적용할 수 있다. 이 증례에서는 상악 중절치의 선천적 결손으로 인하여 대칭성을 구현하기 불가능한 상황에서 $\mathrm{DSD}$ 를 활용하여, 환자 안모와 상악 전치부의 전체적인 조화를 추구하는 것을 목표로 하였으며, 이 를 통해 환자와 술자 모두 만족할 만한 심미적인 결과를 얻었기에 이를 보고하고자 한다.

(구강회복응용과학지 2019;35(3):170-9)

주요어: 심미; 전치부 수복; digital smile design

*교신저자: 이준석

(31116) 충청남도 천안시 동남구 단대로 119 단국대학교 치과대학 치과보철학교실

Tel: 041-550-0256 | Fax: 041-550-1975 | E-mail: jseok2@hanmail.net

접수일: 2019년 5월 19일 | 수정일: 2019년 7월 13일 | 채택일: 2019년 7월 16일 